\title{
KRITIK TERHADAP EKSISTENSIALISME ATEISTIK TENTANG PENOLAKAN EKSISTENSI TUHAN
}

\author{
Alim Roswantoro \\ Dosen Fakultas Ushuluddin UIN Sunan Kalijaga Yogyakarta
}

الملخص

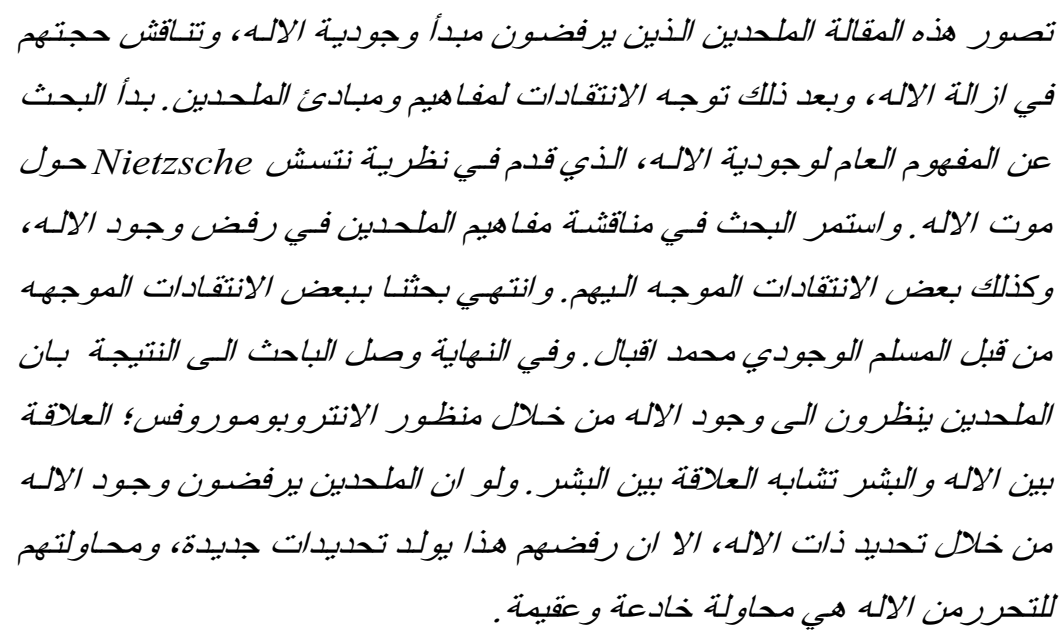

\section{Abstract}

The article describes the atheist existentialists' concept of God, arguments of taking away God, and then tries to criticize their concepts and arguments. General account on existentialists' concept of God, which is represented in Nietzsche's statement on the death of God, begins the paper. The following part is about arguments in denying the existence of God, followed by some critiques of them. The criticism of Muhammad Iqbal, who is a Muslim existentialist, on atheistic existentialistic concept of God ends the thoroughly paper. The result of this research is that atheist existentialists understand 
God in anthropomorphic explanation; the relation between God and human is identical with that of human and human. Even though they denied the existence of God with the reason of determinism, their arguments implied a new determinism, and the freedom they struggled indicated pseudo freedom.

Keywords: eksistentialisme, eksistensi Tuhan, kebebasan manusia, determinisme, hubungan Tuhan-manusia.

\section{A. Pendahuluan}

Perseteruan antara dua kelompok manusia, yaitu mereka yang meyakini adanya Tuhan dan mereka yang mengingkari Tuhan, adalah suatu kenyataan yang terus berlangsung sepanjang perjalanan sejarah. Perseteruan ini tampaknya akan terus berlangsung tanpa akhir. Sampai akhir sejarah manusia, kaum ateis dan kaum teis mungkin akan tetap bisa dijumpai. Mereka menjadi ateis dan teis berdasar pada argumentasiargumentasi filosofisnya masing-masing, yang barangkali akan terus berkembang kualitasnya akibat dari saling kritik antara kedua kelompok ini.

Tuhan yang bagi kaum teis begitu penuh makna, bagi kaum ateis tidak ada artinya dan dianggap mengganggu dalam kehidupan ini. Kata mengganggu mengindikasikan suatu penghalang bagi kebebasan. Kebebasan memang merupakan nilai mendasar dalam kehidupan manusia. Ketiadaan kebebasan berarti ketiadaan proses eksistensial kehidupan manusia. Madjid Fakry menilai kebebasan sebagai prasyarat paling fundamental bagi pertanggungjawaban manusia. ${ }^{1}$ Namun demikian, jika para ateis menganggap kehadiran Tuhan mengganggu bahkan meniadakan kebebasan manusia, para teis justru menilai kehadiran Tuhan sebagai sumber kebebasan manusia. Prasyarat dasar kebebasan sejati, kata kaum teis, justru adalah adanya Tuhan sebagai pusat transendensi. Karena apabila tidak ada Tuhan, kebebasan bisa berkembang menjadi lebih politis, karena untuk menjadi bebas orang harus kuat dan mengatasi orang lain. Dengan mengakui Tuhan, akan muncul pengakuan keagungan dan kekuatan hanya ada pada Tuhan,

${ }^{1}$ Madjid Fakry, Ethical Theories in Islam (Leiden: E. J. Brill, the Nederlands, 1991), p. 19. 
yang pada gilirannya akan menciptakan suatu ekspresi dan aktualisasi kebebasan yang lebih bermoral.

Perseteruan mereka yang sangat populer dalam kajian filsafat memunculkan wacana apakah tindakan manusia telah ditentukan sebelumnya atau tidak. Wacana ini kemudian melahirkan dua paham terkenal yang disebut oleh Goldman dengan determinism atau predictionism dan indeterminism atau anti-predictionism. ${ }^{2}$ Paham pertama mengajarkan bahwa tindakan-tindakan manusia telah ditentukan sebelumnya, sehingga bisa diramalkan, sementara paham kedua menegaskan tidak ditentukan sebelumnya, dan karenanya tidak bisa diramalkan. Kedua paham ini kemudian sangat populer dalam kajian filsafat ketika berbicara tentang problem koeksistensial antara Tuhan dan manusia. Sumber pokok dari problem koeksistensial ini adalah kebebasan.

Pikiran-pikiran para ateis berkenaan dengan problem koeksistensial antara Tuhan dan manusia demi kebebasan, yang paling argumentatif secara filosofis adalah dari kalangan eksistensialis ateis, terutama Friederich Nietzsche ${ }^{3}$ dan Jean-Paul Sartre. ${ }^{4}$ Mereka

${ }^{2}$ Alvin I. Goldman, "Actions, Predictions, and Books of Life," dalam Joel Feinberg (ed.), Reason and Responsibility, Readings in Some Basic Problems of Philosophy (California: Wadsworth Publishing Company Belmont, 1985), p. 401.

${ }^{3}$ Friederich Nietzsche adalah seorang filosof romantis Jerman yang kemudian dikenal sebagai bapak eksistensialis ateis. Dia lahir 15 Oktober 1844. Meski berasal dari keluarga pendeta, sejak usia 18 tahun ia telah meninggalkan agamanya, Kristen. Dia ingin bebas berpikir tanpa keterikatan oleh agama. Di antara karya-karya pentingnya adalah Also Sprach Zarathustra (1883), Jenseit von Gut und Boese (1886), Zur Genealogie de Moral (1887), dan Ecce Homo (1888). Di antara konsep filosofisnya yang terkenal adalah teologi the death of God, the will to power, superman, dan eternal recurrence. Pada tahun 1889, ia menjadi sakit jiwa di Urin Italia. Selama sepuluh tahun dirawat oleh ibu dan kakaknya. Tahun 1900 ia meninggal, terkenal dengan filosof dengan martil, "nabi" kematian Tuhan dan an unphilosophical philosophy. Lihat, Louis Pojman, Philosophy the Pursuit of Wisdom (Belmont: Wadsworth Publishing Company, 1998), p. 347 - 350; Julius Seelye Bixler, "Nietzsche" dalam Vergilius Ferm (ed.), An Encyclopedia of Religion (New York: Philosophical Library, 1976), p. 535.

${ }_{4}^{4}$ Jean-Paul Sartre lahir di Paris tahun 1905 di tengah keluarga Protestan berdarah Swiss-Perancis. Dia adalah salah satu eksistensialis yang dengan terang-terangan menyebut dirinya sebagai seorang ateis, tepatnya eksistensialis ateis. Di antara karya pentingnya adalah L'Etre et le Neant, Essay d'Ontologie Phenomenologique (1943), L'Existentialisme est unj Humanisme (1946), dan Critique de la raison Dialectique (1960). Karya kedua yang disebut di sini, L'Existentialisme est unj Humanisme, dalam bulan 
menantang betul para teis dan mendorong untuk berpikir keras mematahkan argumentasi mereka. Tulisan ini dibuat juga sebagai suatu peninjauan kritis atas argumentasi-argumentasi penolakan eksistensi Tuhan oleh para eksistensialis ateis tersebut. Pilihan tulisan ini pada kedua eksistensialis ateis tersebut karena keduanya sangat berpengaruh dan vokal-argumentatif serta terang-terangan dalam menolak Tuhan. Argumentasi keduanya cukup tajam dan mendalam secara filosofis, dan sudah barang tentu akan kelihatan mudah diterima bagi kaum awam filsafat, apalagi tipologi orang yang tak mau berpikir mendalam. Tulisan ini mencoba mengeksplorasi argumentasi-argumentasi penolakan kedua eksistensialis ateis tersebut, kemudian dengan pendekatan analisis filosofis mencoba melakukan kritik.

\section{B. Pandangan Umum Eksitensialis Ateis tentang Tuhan}

Semua eksistensialis ateis sepakat dengan pernyataan Nietzsche bahwa Tuhan telah mati. Proklamasi Nietzsche tentang the death of God dimaksudkan untuk menghilangkan dasar nilai-nilai budaya Eropa yang dihegemoni oleh agama. Agama katanya telah menghalangi kemajuan Eropa. ${ }^{5}$ Dengan adanya kepercayaan pada Tuhan berarti menghalangi dinamika manusia. Agama, yang dimaksud Nietzsche dengan jelas adalah Kristen, menolak adanya suatu budaya yang diciptakan manusia. Pendeknya, kata Nietzsche, agama berkata "tidak" pada dunia ini. Dalam karyanya The Joyful Wisdom, dengan tegas dia mengatakan bahwa "apa yang ditolak oleh Kristen adalah fakta budaya manusia yang besar."

pertama terjual lebih dari setengah juta kopi. Dalam karya ini pula dia menuangkan gagasan eksistensialisme ateisnya dan membeberkan argumentasi filosofis penolakan Tuhan. Dia tidak pernah menikah secara resmi, tetapi Simone de Beauvoir boleh dianggap sebagai isterinya. Ia meninggal tahun 1980. Ajaran filosofis terkenalnya antara lain adalah absolute freedom dan radical dualism: being-in-itself dan being-for-itself. Lihat, H.J. Blackham, Six Existentialist Thinkers (London: Routledge \& Kegan Paul, 1952), p. 168., Louis Pojman, Philosophy the Pursuit of Wisdom, p. 355 - 356.

${ }^{5}$ St. Elmo Nauman, Jr., The New Dictionary of Existentialism (New York: Philosophical Library, 1971), p. 67.

${ }^{6}$ Friedrich Nietzsche, The Joyful Wisdom, trans. By Thomas Common (London: NTN Voulis, (t.t), p. 50. 
Nietzsche tidak percaya pada Tuhan dikarenakan kepercayaan baginya menunjukkan sikap yang lemah, yang segan mencari kebenaran sampai tuntas. Kepercayaan tidak menunjukkan kehendak yang kuat, yang berani menghadapi kesulitan apa pun. Tampak jelas bahwa ateismenya semula bersembunyi di balik penghargaannya akan kehendak yang kokoh teradap kehidupan yang asli, yaitu hidup yang meriah dan bebas, seperti ditampakkan dalam pesta pemujaan dewa Dynoius. Hidup yang tenang pada hakikatnya bukan hidup lagi. ${ }^{7}$ Dengan demikian, Nietzsche memandang Tuhan sebagai hakikat yang bertentangan dengan hidup.

Dengan kesimpulannya seperti itu, Nietzsche kemudian memaklumatkan ateismenya dengan pernyataan, Tuhan telah mati, manusialah sang pembunuhnya. Nietzsche berkata:

Adakah kamu pernah mendengar orang gila itu, pada hari dengan sinar yang cerah berlari ke tengah-tengah pasar yang tak putus-putusnya berteriak, saya mencari Tuhan, saya mencari Tuhan. Orang gila itu meloncat ke tengah dan memandang dengan tajam kepada mereka, ke mana Tuhan menghilang? Ia berteriak, saya bermaksud menceritakan kepadamu, kita telah membunuhnya, kau dan aku, kita semua adalah pembunuh Tuhan. ${ }^{8}$

Pernyataannya ini ditujukan untuk menyerang secara langsung segala anggapan yang mengakui kekuatan supernatural. Menurutnya, kesadaran manusia telah sedemikian dirasuki oleh agama, sehingga tidak dapat lepas dari anggapan akan adanya Tuhan. Kepercayaan kepada Tuhan yang dibina oleh agama yang demikian berakar dapat dilihat dalam sejarah filsafat di Eropa. Filsafat belum benar-benar merdeka, masih dirembesi teologi. ${ }^{9}$

Barangkali, maksud Nietzsche ini bisa dipahami, karena meskipun setelah abad Pertengahan orang sudah menolak peran filsafat sebagai sekedar abdi teologi, namun, misalnya Descartes dan Hegel pada akhirnya terjebak pada Realitas Mutlak. Rasionalitas Descartes

${ }^{7}$ A. Sudiardja, "Pergulatan Manusia dengan Allah dalam Antropologi Nietzsche," dalam M. Sastrapratedja (ed.), Manusia Multi Dimensional Sebuah Renungan Filsafat (Jakarta: PT. Gramedia, 1983), p. 6.

${ }^{8}$ Friedrich Nietzsche, The Joyful Wisdom ..., p. 167.

${ }^{9}$ A. Sudiardja, "Pergulatan ..., p. 6-7. 
yang dengan meragukan seluruh realitas bermaksud mendapatkan kepastian yang jelas dan tegas, pada akhirnya menyerah pada ide bawaan dan adanya Tuhan sebagai postulat yang harus diterima, sedangkan Hegel mengakui perkembangan dialektis dari apa yang disebutnya Roh Absolut. "Racun" teologis dari Kristen, menurut anggapan Nietzsche, yang merasuki filsafat dan kebudayaan Eropa ini membuatnya muak dan membenci Tuhan Kristiani, dan bahkan kemudian membunuhnya. Dengan nada pedas dan mengejek, ia menggambarkan kematian Tuhan sebagai berikut: "Tidakkah kita mendengar kesibukan para penggali kubur yang sedang mengubur Tuhan? Apakah kita tidak mencium bau bangkai Tuhan? Bahkan Tuhan telah manjadi busuk. Tuhan mati. Tuhan akan tetap mati, dan kita telah membunuhnya." ${ }^{10}$

Kritik tajamnya terhadap agamanya yang tersebar dalam berbagai karyanya yang puncaknya pada buku AntiChrist ini, membuatnya dikenal sebagai seorang ateis yang paling ekstrem. ${ }^{11}$ Kematian Tuhan ditegaskannya karena ia harus memilih satu di antara dua: Tuhan atau manusia. Ungkapan tentang Tuhan tersebut bukanlah suatu ratapan, melainkan hanya sekedar pilihan. Tuhan hidup, manusia mati, atau sebaliknya, manusia hidup dan Tuhan harus mati. Keduanya tidak mungkin hidup bersama. ${ }^{12}$

Seperti halnya pandangan materialisme, Ludwig A. Fuerbach misalnya, mengatakan teologi harus menjadi antropologi. Menurut Feuerbach, teologi itu penting, tetapi bukan sebagai ajaran tentang Tuhan, melainkan sebagai antropologi, ajaran tentang manusia. Teologi mengajarkan banyak sekali tentang manusia. Manusia adalah pusat, permulaan, dan akhir agama. Karena itu, teologi harus dibaca antropologi. Baginya, manusia tidak diciptakan oleh Tuhan, tetapi

\footnotetext{
${ }^{10}$ Friedrich Nietzsche, The Joyful Wisdom, p. 167.

${ }^{11}$ Choirul Arifin, Kehendak untuk Berkuasa Friedrich Nietzsche (Jakarta: Penerbit Airlangga, 1987), p. 11.

${ }^{12} \mathrm{Ibid}$. hlm. 7. Moltmann menjelaskan pilihan ini didasarkan pada argumentasi kebebasan, karena bagi para eksistensialis ateis seperti Nietzsche dan juga Sartre, kombinasi antara Tuhan dan kebebasan adalah mustahil. Jika kombinasi itu mungkin, maka tiada makna berbicara kebebasan. Dia mengatakan dalam tulisannya The Risks of Freedom, lihat Juergen Moltmann, "The Risks of Freedom," dalam Werner Becher, Alastair V. Campbell, and G. Keith Parker (eds.), The Risks of Freedom (Manila: the Pastoral Care Foundation, Inc., 1993), p. 26.
} 
Tuhanlah yang diciptakan manusia. ${ }^{13}$ Sama dengan proyeksi Feuerbach, Nietzsche dengan membunuh Tuhan berusaha mengembalikan perhatian hanya pada manusia. Pergeseran dari dunia transenden ke dunia imanen. Inilah yang menjadi tujuan dari teologinya tentang the death of God, sebagaimana ditulis Altizer dan Hamilton: "Kematian Tuhan memberi kesaksian terhadap datangnya suatu momen sejarah baru. Momen yang mengubah transendensi ke dalam imanensi, dengan demikian, membubarkan dasar-dasar dari subjektivitas dan kehidupan batin agama." ${ }^{14}$ Kehilangan dunia lama, yaitu manusia dengan Tuhan, dapat diimbangi dengan menciptakan suatu dunia baru, yaitu manusia tanpa Tuhan. Manusia baru itu menjadi dewa baru, yaitu manusia super (superman, Uebermensch), yang sarat dengan kehendak hidup dan nafsu kekuasaan. Demikian pendapat Nietzsche, yang dengan tajam menggambarkan manusia super ini dalam bukunya Thus Spake Zarathustra. ${ }^{15}$ Baginya, eksistensi manusia adalah terbuka atas dasar dorongan kehendak bebas dalam diri manusia, seperti dinukil oleh Will Durant:

Seorang manusia begitu lahir dan berkembang akan melampaui kebaikan dan kejahatan; ... dia akan menjadi tanpa takut daripada menjadi baik. Apakah kebaikan itu? ... Menjadi berani adalah kebaikan. Apakah kebaikan itu? Semua yang meningkatkan perasaan berkuasa, kehendak untuk menguasai, kekuasaan itu sendiri, dalam diri manusia. Apa yang buruk? Semua yang berasal dari kelemahan. ${ }^{16}$

\footnotetext{
${ }^{13}$ Harry Hammersma, Tokoh-tokoh Filsafat Barat Modern (Jakarta: PT. Gramedia, 1983), p. 64-5.

${ }^{14}$ Thomas J.J. Altizer and William Hamilton, Radical Theology and the Death of God (New York: The Bobb Merrill Company, Inc., 1966), p. 10.

${ }^{15}$ Friedrich Nietzsche, Thus Spake Zarathustra, trans. By Thomas Common (London: George Allen \& Unwin Ltd., 1967).

${ }^{16}$ Will Drant, The Story of Philosophy (New York: Pocket Books, Inc. 1954), p. 426. Kebaikan adalah keberanian untuk menjadi diri dari diri sendiri, tanpa bayangan apa pun dari kekuatan yang mendahului eksistensinya. Untuk menjadi diri yang sejati harus berkuasa, karena dikuasai adalah kelemahan. Nietzsche dengan tegas menggarisbawahi bahwa satu kelemahan besar manusia Eropa adalah memiliki suatu kepercayaan pada sesuatu yang adikodrati, Tuhan. Oleh karena itu, kepercayaan, yang kristalisasinya adalah agama, adalah kelemahan, dan kelemahan adalah lonceng kematian, dan liang lahat bagi kehidupan.
} 
Demikian secara umum pandangan Tuhan seorang eksistensialis ateis, Nietzsche. Eksistensi manusia adalah bebas mendahului segala definisi tentang manusia itu sendiri. Ancaman kebebasan terbesar baginya untuk eksistensi manusia adalah eksistensi Tuhan.

Eksistensialis lain, yang memproklamasikan dirinya sebagai eksistensialis ateis, yang sangat vokal menentang gagasan tentang Tuhan dan menggantikannya dengan gagasan the absolute freedom adalah JeanPaul Sartre. Dia sangat terinspirasi oleh Nietzsche, dan salah satu pengibar teologi the death of God-nya. Tuhan sering dan berulang-ulang disebut dalam tulisannya, tetapi tetap saja untuk ditolak kehadirannya di tengah-tengah kehidupan manusia.

Dalam karyanya Existentialism and Human Emotions, ${ }^{17}$ Sartre mempersoalkan Tuhan sebagai pencipta, God as Creator. Tuhan mencipta berdasarkan ide tertentu tentang realitas yang akan diciptakan. Dengan demikian, Tuhan mengetahui esensi benda-benda, termasuk manusia, yang telah diciptakan-Nya itu. Proses dan cara Tuhan mencipta ini, ia analogikan dengan seorang ahli pembuat pisau pemotong kertas (paper cutter), yang sebelumnya telah didahului oleh suatu gagasan tentang kepisau-kertasan. Katanya, "Ketika kita memahami Tuhan sebagai pencipta, Dia secara umum dianggap sebagai semacam seorang yang sangat ahli." " Jelas bahwa oleh Sartre Tuhan disamakan dengan seorang tukang. Tuhan yang tukang itu membuat objek-objek, termasuk manusia, menurut konsep yang sudah jadi dan statis, sama seperti sang perancang membuat pisau pemotong kertas. Menurut kesimpulannya:

Dengan demikian, konsep manusia yang ada dalam pikiran Tuhan dapat dibandingkan dengan konsep pisau pemotong kertas yang ada dalam pikiran sang perancang, dan melalui teknik-teknik serta konsep tertentu, Tuhan menciptakan manusia, sama seperti si tukang yang melalui suatu definisi dan teknik membuat pisau pemotong kertas. Jadi individu manusia merupakan realisasi dari suatu konsep tertentu yang ada dalam intelegensi Tuhan. ${ }^{19}$

${ }^{17}$ Jean-Paul Sartre, Existentialism and Human Emotions, trans. by Bernard Frechtman (New York: Philosophical Library, 1948).

${ }^{18}$ Ibid. p. 14.

${ }^{19}$ Ibid. 
Menurut Sartre, dan para eksistensialis ateis pada umumnya, konsepsi seperti itu menghancurkan kebebasan manusia. Karena Tuhan menjadi serba tahu dan serba kuasa. "Kalau Allah maha tahu, tidak ada yang tinggal bagiku untuk kutemukan; aku selalu menemukan halhal yang sudah diketahui." ${ }^{20} \mathrm{Hal}$ ini berarti bahwa tidak ada keaslian tindakan manusia. Seorang manusia tidak dapat mengubah secara hakiki dan tidak dapat mencapai taraf lebih tinggi daripada yang telah ditentukan oleh Tuhan.

Dalam benaknya, Sartre lebih menonjolkan penampakan persaingan antara manusia dan Tuhan daripada hubungan yang saling memberi kepenuhan eksistensi pada keduanya. Dalam sandiwara Les Mouches (The Flies, lalat-lalat), sebagaimana dinukil oleh Louis Leahy, ${ }^{21}$ Tuhan digambarkan sebagai sang polisi yang hanya dapat menghancurkan kebebasan manusia. Dalam sandiwara itu, Tuhan dinamakan Jupiter. Lalat-lalat melambangkan penyesalan-penyesalan yang menghantui para penduduk kota Argos yang dikuasai oleh raja Egisthe. Sang raja membunuh Agammemnon untuk mengawini istrinya, Clytemnestre.

Pembunuhan ini didakwakan raja sebagai kesalahan seluruh warga kota, sehingga mereka setiap tahunnya harus berdo'a, "kasihanilah kami, karena kami hidup," sebagai tanda pemujaan mereka kepada Jupiter. Jupiter terus mengaktifkan rasa kesedihan dan penyesalan mereka agar tidak melakukan pemberontakan. Electre, anak putri Agammemnon, menjadi pelayan domestik kerajaan, dan dibenci raja karena memberontak atas pembunuhan ayahnya dan menentang cara realigius yang dilakukan seluruh penduduk kota, karena paksaan dari raja. Sementara Oreste, anak putra Agammemnon, yang selamat karena pendidikannya, bermaksud membunuh raja Egisthe. Jupiter tahu dan berusaha mencegahnya, tetapi gagal, kemudian dia memberitahukan hal itu pada Egisthe untuk menghentikan dan memenjarakannya. Tetapi, Egisthe justru merasa bersalah dan bersedia dibunuh karena putus asa, bosan, dan pantas dihukum.

${ }^{20}$ Nico Syukur Dister OFM, Filsafat Kebebasan, (Yogyakarta: Penerbit Kanisius, 1993), p. 29 
Ada dialog antara Oreste dan Jupiter, dan antara raja Egisthe dan Jupiter. Dari dialog ini, paham ketuhanan Sartre tampak jelas. Jupiter tidak mampu menangkis kata Oreste, "Engkau hanya bisa memerintah orang-orang yang kurang bebas. Terhadap mereka yang berani dan bebas Engkau bukan Tuhan lagi." Egisthe pernah bertanya pada Jupiter, "mengapa Engkau mau menghindarkan Oreste membuat kejahatan itu, sedangkan dahulu Engkau tidak mencegahku membunuh Agammemnon?" Jupiter menjawab, "karena kedua hal banyak bedanya. Saya sudah menerka bahwa setelah kejahatanmu, kamu akan tetap hidup dalam ketakutan dan kesedihan. Bukan hanya kamu, tetapi juga seluruh kota Argos. Sebaliknya, kejahatan Oreste tidak akan menimbulkan penyesalan apa pun, karena dia tidak mempedulikan kewibawaan saya. Dengan kata lain, kejahatanmu adalah kejahatan yang bermanfaat."

Dalam sandiwara tersebut, kemahatahuan Jupiter justru menimbulkan kerumitan pemecahan atas dua kejahatan yang memunculkan pertanyaan keadilan oleh Egisthe, bahkan seolah Jupiterlah yang berbuat salah dan jahat. Penggambaran Tuhan dalam sandiwara itu mencerminkan dengan jelas seluruh iklim etik atau moralitas Tuhan yang jelek dan negatif. Dengan pemahaman Tuhan seperti itu, Sartre menegaskan bahwa "Tuhan adalah suatu hipotesa yang tidak berguna dan merugikan." 22 Dia justru menjadikan Tuhan sebagai proyeksi fundamental manusia. Katanya, "Cara terbaik untuk memahami proyeksi fundamental dari realitas manusia adalah mengatakan bahwa manusia adalah wujud yang proyeksinya adalah menjadi Tuhan." 23 Atau katanya lagi, “...manusia secara fundamental adalah hasrat untuk menjadi Tuhan." ${ }^{24}$

${ }^{21}$ Louis Leahy, Aliran-aliran Besar Ateisme Tinjauan Kritis (Yogyakarta: Penerbit Kanisius, 1992), p. $73-74$.

22 "Sartre: Existentialist Ethics," dalam James A. Gould (ed.), Classic Philosophical Questions, (Columbus: Charles E. Merrill Publishing Company a Bell \& Howell Company, 1971), p. 203.

${ }^{23}$ Jean-Paul Sartre, Existentialism and Human Emotions, p. 63.

${ }^{24}$ Ibid. Pernyataannya ini jika dicermati dengan baik tampak pengaruh kuat dari Nietzsche. Jika bagi Nietzsche proyeksi hidup manusia adalah kehendak untuk berkuasa, menjadi manusia super, dalam bahasa Sartre superioritas manusia disimbolkan dengan istilah Tuhan. Tujuan utama manusia adalah proyeksinya menjadi Tuhan, bukan 


\section{Argumentasi Penolakan Eksistensi Tuhan}

Secara umum, argumentasi pokok yang diajukan oleh eksistensialis ateis dalam menolak eksistensi Tuhan adalah kebebasan manusia. Jika Nietzsche lebih menekankan aspek kritik atas dominasi teologi Kristen atas pengetahuan dan kebudayaan, Sartre memperhatikan secara serius pada masalah ontologis, perlunya mengkaji ide tentang ada dan juga menekankan ide tentang ketiadaan, walaupun ide ini kemudian oleh Sartre dijabarkan dalam pengertian yang lebih Hegelian daripada Heideggerian. ${ }^{25}$

\section{Argumentasi dari Otonomi Kebebasan}

Ciri umum dari eksistensialisme adalah eksistensi mendahului esensi. Heidegger mengatakan, karena manusia "terlempar" ke dunia tanpa diketahui sebabnya dan tidak terelakkan, berarti ini merupakan penegasan fundamental dari filsafat eksistensi bahwa manusia ada tanpa menemukan suatu alasan adanya dia, manusia adalah eksistensi tanpa esensi. Dengan kata lain, esensi-esensi manusia semata-mata hanya merupakan konstruksi-konstruksi dari manusia di dalam proses eksistensinya. ${ }^{26} \mathrm{Hal}$ ini berarti merupakan otonomi kebebasan manusia. Berdasar otonomi ini, menurut Heidegger, manusia harus meninggalkan skema klasik, “ ... suatu hirarki realitas yang puncaknya adalah Tuhan, ada yang paling sempurna." ${ }^{27}$ Otonomi kebebasan ini dibahasakan oleh Nietzsche dengan munculnya manusia sebagai pencipta tunggal di dunia ini, karena dorongan kehendak bebas dan kehendak untuk berkuasa; sehingga Tuhan harus tidak ada atau dibunuh. Bagi Sartre, karena eksistensi mendahului esensi berarti manusia tidak dapat didefinisikan oleh suatu konsep apa pun, manusia sendiri yang mengkonstruksi nilai-nilai, norma-norma hukum, dan pendeknya esensi-esensinya. Tidak ada determinisme, manusia adalah bebas, manusia adalah kebebasannya. Dalam dimensi pemikiran

ditentukan Tuhan. Gagasan yang ingin diusung oleh keduanya adalah sama, kebebasan harus tanpa Tuhan. Tuhan hanya akan menjadi pengacau kebebasan.

${ }^{25}$ Jean Wahl, A Short History of Existentialism, trans. by Forrest Williams and Stanley Maron (New York: Philosophical Library, 1949), p. 28.

${ }^{26}$ Ibid., p. 14.

${ }^{27}$ Ibid. 
fenomenologis, Sartre mengungkapkan manusia adalah kebebasan "by isolating being-for-itself from facticity." 28 Maksudnya adalah kesadaran sebagai penidakan (nibilation), artinya "ketika saya sadar terhadap sesuatu, maka saya meniadakan sesuatu itu." 29 Sebagai contoh, jika saya menemukan sebuah batu dan saya sadar bahwa itu batu, maka saya langsung melakukan nihilasi bahwa saya bukanlah batu. Oleh karena itu, conciousness (being-for-itself) adalah bebas dan tanpa dasar dukungan. Kata Sartre, "Ciri khas being-for-itself menunjukkan bahwa ia adalah ada yang tidak mendapatkan bantuan, dasar dukungan dalam apa yang telah ada." ${ }^{\prime 30}$ Jadi, kesadaran selalu adalah kesadaran terhadap being-for-itself dan sekaligus nihilasi murni terhadapnya. Konsekuensinya adalah bahwa kebebasan sebagai transendensi merupakan otonomi absolut. Ini berarti manusia harus melepaskan diri dari ketergantungan transendental; menolak ketergantungan manusia pada Tuhan. "Tuhan bukanlah raja manusia, karena manusia adalah bebas. Jika Tuhan ingin mengatur manusia, Dia seharusnya tidak menciptakan manusia sebagai ada yang bebas." 31

Penggambaran Tuhan sebagai Pencipta dan dengan atributatribut superlative, seperti mahatahu, mahakuasa, dan mahaperkasa, menurut Sartre merupakan pandangan yang menghacurkan kebebasan manusia. Karena manusia direduksi kepada sesuatu seperti a papercutter, kepada wujud, yaitu apa yang ada kepada faktisitas murni, kepada benda. Bagaimanapun, manusia tidaklah demikian, manusia bukanlah apa yang ada, dan apakah dia tidak ada, manusia adalah proyeksi, dan sebagai transendensi manusia adalah pelaksanaan dari proyek itu. ${ }^{32}$ “...Jika Tuhan tidak ada, maka manusia tidak menemukan nilai-nilai atau perintah-perintah yang melegitimasi perilaku manusia." ${ }^{33}$

${ }^{28}$ William A. Luijpen, Existential Phenomenology (New York: Duquesne University Press, Pittsburgh, Pa., 1960), p. 316.

${ }^{29}$ Ibid., p. 105.

${ }^{30}$ Jean-Paul Sartre, Being and Nothingness, an Essay on Phenomenological Ontology, trans. by H. Barnes (New York: Philosophical Library, 1956), p. 479.

${ }^{31}$ William A. Luijpen, Existential Phenomenology, p. 316.

${ }^{32}$ Ibid., p. 317.

${ }^{33}$ Jean-Paul Sartre, Existentialisme and Human Emotions, p. 23. 


\section{Argumentasi dari Intersubjektivitas}

Alasan kedua menolak Tuhan didasarkan pada problem intersubjektivitas; hadirnya orang lain atau yang lain dalam dunia individu manusia. Sartre menguraikan fenomenomlogi mengenai pandangan orang lain. Tetapi ilustrasi-ilustrasi yang diberikan semuanya dalam situasi ancaman, seperti pengintip yang dipergoki; penonton yang membuatku tersandung di panggung; orang-orang di "neraka" tahu bahwa mereka ada, mereka tahu mengenai pendapat orang lain mengenai diri mereka. ${ }^{34}$ Dari pandangan ini, Sartre memulai argumentasinya dengan mempertanyakan, siapakah Tuhan itu, jika memang ada Tuhan? Menurutnya, "Dia adalah yang lain yang paling unggul." 35 Tetapi, apakah penghayatan subjektivitas yang lain itu berarti bagi saya? Menghayati subjektivitas yang lain berarti menghayati pandangannya, yaitu menghayati wujudku yang dilihat. Pandangan orang lain atau yang lain yang mengarah ke saya itu mengubah saya menjadi objek. Objektivikasi ini adalah kejam, karena hal ini berakibat eksistensi saya yang bebas dibekukan. ${ }^{36}$ Pandangan ini mengimplikasikan "matinya subjektivitasku sebagai suatu proyeksi, sebagai transendensi, sebagai kebebasan." 37 "Di bawah pandangan yang lain, saya tampak sebagai suatu benda-dalam-dunia ini, saya adalah apa yang saya ada. Ada-untuk-yang-lain-ku berarti bahwa saya dirampas dari transendensi saya." ${ }^{38}$ Dalam kondisi-kondisi seperti ini, tidak ada suatu persoalan pengakuan akan Tuhan, karena manusia tidak ingin melepaskan subjektivitasnya.

Tuhan adalah Yang lain par excellence, yang berarti Dia adalah yang satu yang memandang semua subjek, sebelum kepadanya pengalaman mereka sendiri sebagai objek, yang satu yang kehadiran-Nya tidak dapat ditahan terhadap suatu subjek. Tuhan adlah wujud yang hanya melihat, tetapi Dia sendiri tidak dapat dipandang oleh sesuatu apapun. ${ }^{39}$

${ }^{34}$ C.A. van Peursen, Orientasi di Alam Filsafat, terj. Dick Hartoko (Jakarta: PT. Gramedia, 1980), p. 224.

${ }^{35}$ William A. Luijpen, Existential Phenomenology, p. 316.

${ }^{36}$ Fuad Hassan, Berkenalan dengan Eksistensialisme (Jakarta: Pustaka Jaya, 1992), p. 146.

${ }^{37}$ William A. Luijpen, Existential Phenomenology, p. 316.

${ }^{38}$ Ibid.

${ }^{39}$ Ibid. 
Menerima Tuhan, karenanya, akan berarti menerima wujud suatu benda murni. Mengakui Dia berarti berada secara asing, teralienasi dari kemanusiaan yang dipahami sebagai kebebasan. Tetapi, apakah hal ini benar bahwa saya harus mengakui Tuhan dan bahwa kebebasan adalah sebuah ilusi? Secara terbatas tidak benar, karena manusia adalah bebas, dan konsekuensinya, tidak ada Tuhan. Sebagaimana Sartre, yang berlawanan dengan konsep idealistik, kurang menekankan persaudaraan segenap umat manusia, Nietzsche pun menganggap pikiran-pikiran kesamaan derajad antar manusia adalah hal yang mustahil. Dalam hubungan antar manusia, yang harus ditumbuhkan adalah manusiamanusia unggul, yang dengan kekuatannya bisa mengatasi kumpulan manusia dalam massa; manusia mampu mengangkat dirinya dari kehanyutan dalam massa. Kemampuan manusia seperti ini tidak mendapat bantuan dari siapa pun, tidak juga dari kekuatan yang disebut Tuhan. ${ }^{40}$ Manusia adalah satu-satunya pencipta dan bebas berkreasi, oleh karena itu, Tuhan harus tidak ada. Jika Sartre memandang yang lain atau orang lain sebagai ancaman bagi eksistensi dirinya, bagi Nietzsche orang lain atau yang lain adalah para pesaing-pesaingnya.

\section{Argumentasi dari Kontradiksi Internal Tuhan dan Makna Hidup}

Membaca uraian ontologis Sartre tentang ada-dalam-diri (beingin-itself) dan ada untuk diri (being-for-itself) didapati kesimpulan bahwa ia berpandangan dualisme radikal. Pandangan ini secara konsekuen dipegangi sampai pada penolakannya pada Tuhan. Katanya, "Hidup adalah absurd, karena manusia adalah suatu upaya pendewaan-diri, dan Tuhan adalah suatu kontradiksi." ${ }^{\prime 1}$ Dengan memakai konsep tentang being-in-itself dan being-for-itself, dia berusaha karas membuat suatu pandangan tentang Ada, yang oleh agama-agama disebut dengan Tuhan. Ada-dalam-diri, tidak seperti kesadaran, adalah apa yang ada secara penuh identik dengan dirinya sendiri, tidak ada aktivitas nihilasi atau penidakan yang merupakan ciri dari kesadaran. Ia adalah tanpa negativitas dan positivitas secara penuh. Ia adalah kepenuhan yang ada tanpa memerlukan sesuatu yang lain yang ada. Sartre berpikir, atas

\footnotetext{
${ }^{40}$ Fuad Hassan, Berkenalan dengan Eksistensialisme, p. 42.

${ }^{41}$ William A. Luijpen, Existential Phenomenology, p. 319.
} 
dasar dalil kecukupan-diri ini, bahwa Tuhan yang dibicarakan oleh agama adalah berwujud being-in-itself. Karena Tuhan dipahami sebagai suatu wujud yang memiliki kepenuhan ada, suatu wujud yang secara penuh mencukupi-diri dan tidak membutuhkan sesuatu yang lain yang ada. Pada saat yang sama, Tuhan dipahami sebagai being-for-itself, sebagai kesadaran. Menurut karakterisasi Sartre, being-for-itself sama sekali berlawanan dengan being-in-itself. Being-for itself adalah negativitas murni dan membutuhkan being-in-itself untuk menjadi sadar. Pendeknya, adauntuk-diri tidak pernah merupakan kecukupan diri. Aktivitas being-foritself menyatakan diri sebagai nihilasi terhadap masa lampau, terhadap keadaan final, atau ringkasnya terhadap ada. Aktivitas ini berarti mengandaikan ada sebelumnya telah disamakan dengan ada sebagai benda atau ke-benda-an. Dalam Tuhan, being-in-itself dan being-for-itself harus tergabung secatra mutlak. Tetapi, menurut Sartre, itu adalah kontradiksi. Mustahil Tuhan adalah positivitas murni dan sekaligus negativitas murni, kecukupan-diri dan sekaligus ketidakcukupan-diri. Ini adalah bukti kontradiksi, Tuhan adalah suatu kontradiksi internal.

\section{Kritik atas Penolakan Eksistensi Tuhan demi Kebebasan}

Intisari dari penolakan eksistensi Tuhan oleh para eksistensialis ateis, dalam hal ini terutama Nietzsche dan Sartre, adalah problem koesistensi antara manusia dan Tuhan. Bagi mereka, kombinasi antara keduanya adalah tidak mungkin. Jika Tuhan tidak ada, muncul pertanyaan untuk mereka, bagaimana mereka menjelaskan asal-usul adanya manusia, jika adanya tidak diciptakan oleh siapa pun? Jika kebenaran adalah subjektif dan subjektivitas itu sendiri, lalu bagaimana mereka menggambarkan kesalahan?

Para eksistensialis ateis membenarkan bahwa adanya manusia pertama kali memang tidak diciptakan oleh siapa pun, termasuk oleh dirinya sendiri. Sartre berpandangan bahwa adanya manusia pertama kali tidaklah diciptakan dan manusia pun tidak menciptakan dirinya sendiri, ia ada begitu saja dalam suatu keberadaan. Dia sendiri mengatakan, manusia pertama kali ada begitu saja dan kemudian ia mendefinisikan dirinya sendiri, meskipun pada kenyataannya manusia, katanya, tidak pernah didefinisikan berdasar pada prinsip nihilasinya, karena memang ia adalah ketiadaan. Para eksistensialis ateis hanya 
mengatakan ada begitu saja tanpa bisa menjelaskan sebab adanya, dan memamng mereka menghindari membicarakan sebab tersebut, karena penyimpulan adanya sebab pada mulanya adalah suatu determinasi. Bagaimanapun, penghindaran ini adalah suatu kelemahan ontologis, atau lebih merupakan suatu simplisitas ontologis.

Ketika bicara tentang ketiadaan, maka sulit untuk ditegaskan apakah ketiadaan itu ada atau tidak. Apabila dikatakan bahwa ketiadaan itu ada, berarti ia bukan ketiadaan lagi, karena ia ada. Apabila dikatakan ketiadaan itu tidak ada, berarti yang ada bukanlah ketiadaan melainkan ke-ada-an. Jika ketiadaan itu adalah asal dari manusia, sebagaimana diungkap oleh Sartre, maka manusia selalu melakukan nihilasi atau penidakan terhadap putusan-putusan pilihannya yang telah menjadi masa lampaunya, atau pendeknya terhadap realitas kediriannya, maka manusia tidak pernah menyatakan afirmasi terhadap realitas. Penggambaran ini dengan sendirinya sudah merupakan suatu determinasi, karena polanya pasti, atau merupakan esensi manusia. Jadi, penolakan mereka terhadap adanya esensi yang mendeterminasi dan mengkooptasi perilaku manusia, ternyata tidak konsisten. Meskipun mereka telah menolak Tuhan dengan dalih terkungkungnya kebebasan manusia oleh esensi-esensi yang diciptakan Tuhan, namun mereka telah mengukuhkan "Tuhan" baru, yakni ketiadaan. Esensi dari Tuhan baru ini mewujud dalam bentuk "keabadian-penidakan" atau "keabadiannihilasi," yang berarti juga suatu determinasi. Bukan merupakan determinasi justru jika manusia tidak hanya melakukan aktivitas nihilasi, tetapi secara bebas juga melakukan hal sebaliknya. Ini tentu tidak menyalahi arti kebebasan dan tidak harus disebut sebagai kontradiksi.

Nietzsche mengantisipasi tidak diciptakannya manusia, baik oleh wujud di luar manusia maupun oleh manusia sendiri, dengan berpandangan bahwa sejarah akan mencapai kesudahannya dalam manusia super. Dia mengatasi kesudahan ini dengan keyakinan yang bersifat siklis, yaitu bahwa tiap kesudahan menuntut adanya permulaan baru, oleh karenanya secara terus menerus segala sesuatu kembali lagi pada awalnya, sehingga sejarah adalah semacam roda yang berputar. ${ }^{42}$

${ }^{42}$ Harun Hadiwijono, Sari Sejarah Filsafat Barat 2 (Yogyakarta: Penerbit Kanisius, 1993), p. 129. 
Dari pandangan siklis itu muncul pertanyaan, kapan roda sejarah itu dimulai dan dimana pusatnya? Jawaban Nietzsche terurai dalam karyanya the Spake Zarathustra, seperti dikutip Louis Leahy,

Segala sesuatu pergi, segala sesuatu datang kembali; berputarlah roda hakikat itu secara abadi. Segala sesuatu itu mati, segala sesuatu itu berkembang lagi; berlangsunglah rangkaian hakikat itu secara abadi. Segala sesuatu hancur, segala sesuatu disusun kembali; berdirilah hakikat yang sama secara abadi. Lingkaran hakikat tetap setia pada dirinya sendiri secara abadi. ... Hakikat itu mulai pada setiap saat.... Pusatnya adalah di mana-mana. Jalan kekekalan itu melingkar. ${ }^{43}$

Bagi Nietzsche, siapa pun yang menolak ajaran ini, ia harus percaya kepada Tuhan yang berdaulat mutlak. ${ }^{44}$ Berpijak pada solusi siklis di balik keyakinannya bahwa Tuhan telah mati ini, berarti Niezsche terjebak pada determinasi eternal recurrence atau perulangan keabadian, sehingga kebebasan manusia menjadi semu, karena manusia dalam putaran roda sejarah tidak lebih seperti robot dengan mekanik putar. Jika diputar, ia akan bergerak dan kemudian berhenti; pola gerak itu akan selalu sama meskipun mesin diputar berulang-ulang.

Jika memang akhirnya sama-sama tidak bisa atau sulit lepas dari keterjebakan ke alam determinisme dan esensialisme, ketika berbicara dan harus menjelaskan asal pertama kali manusia muncul ke dalam keberadaan, mengapa harus menolak adanya Tuhan sebagai yang menciptakan manusia. Jika diajukan alasan karena kebebasan manusia, yang diakui oleh eksistensialis ateis bahwa kebebasan tidaklah merupakan hasil pemberian manusia kepada dirinya sendiri, dan memang tidak ada aliran pemikiran yang mengajarkan bahwa manusia sendirinlah yang memberikan kebebasan bagi dirinya, lalu mengapa harus diingkari bahwa kebebasan tersebut dianugerahkan kepada manusia oleh Tuhan. ${ }^{45}$

Mengenai pertanyaan bagaimana mereka menggambarkan kesalahan, apabila kebenaran adalah subjektif, ada kritik yang bisa diajukan. Jika keberan bersifat subjektif maka kesalahan juga bersifat

${ }^{43}$ Louis Leahy, Aliran-aliran Besar Ateisme, p. 20 - 21.

${ }^{44}$ Ibid., p. 21.

${ }^{45}$ Muhammad Husayni Bahesty dan Javad Bahonar, Dasar Pemikiran Filsafat Islam dalam Al-Qur'an, terj. Sofyan Abubakar (Jakarta: Risalah Masa, 1991), p. 145. 
subjektif. Jika kebenaran dan kesalahan adalah subjektif, maka bagaimana membedakan kebenaran dari kesalahan. Sidney Hook menyatakan bahwa kaum eksistensialis tidak memiliki jawaban untuk hal itu. Muncul suatu pertanyaan, dapatkan manusia hidup dalam dunia, di mana tidak terdapat perbedaan dan pembedaan antara kebenaran dan kesalahan? Jadi, soal kebenaran itu adalah subjektif tidak mungkin bisa cukup di bidang apa pun, di mana bukti harus diperhitungkan. ${ }^{46}$

Di depan telah diurai penolakan Tuhan sebagai pencipta. Para eksistensialis ateis menyoal, jika Tuhan sebagai pencipta adalah penyebab segalanya di dalam makhluk-makhluk-Nya, bagaimanakan dapat dikatakan bahwa manusia mempunyai kebebasan bertindak, sehingga tindakan-tindakannya itu benar-benar merupakan tindakannya sendiri? Banyak orang telah benar-benar terganggu oleh pertanyaan sulit yang telah menimbulkan debat sengit di masa lampau tersebut. Keberatan-keberatan yang dilontarkan oleh para eksistensialis ateis itu tidak bisa tidak harus dihadapi dan penting sekali dibicarakan, serta sejauh mungkin diatasi, karena muncul dalam hati begitu banyak orang biasa, dan bukan hanya di kalangan orang-orang terpelajar.

Membaca dan mencermati pandangan eksistensialis ateis tentang Tuhan dan alasan-alasan mereka menolak adanya Tuhan, dapat disimpulkan bahwa mereka telah menyetarakan Tuhan dengan manusia. Karena tindakan Tuhan berada pada taraf yang sama dengan tindakan manusia, menurut anggapan mereka, maka kegiatan ilahi meniadakan kepadatan eksistensi manusia. Jalan pikiran seperti inilah yang merupakan kesulitan yang mereka hadapi, disebabkan oleh semacam antropomorfisme dalam anggapan mereka tentang Tuhan. ${ }^{47}$ Bahkan dalam diri Sartre, visi antropomorfisme ini tampak begitu jelas. Tuhan disamakan dengan tukang pembuat pisau-pemotong- kertas. Digarisbawahi oleh Leahy bahwa secara fundamental Tuhan digambarkan sedemikian rupa, sehingga Dia tidak bertahan terhadap kritik orang-orang serius. Manusia, sebagaimana benda-benda lainnya, diciptakan oleh Tuhan dalam konsep jadi dan sekaligus konsep jadi itu

${ }^{46}$ Harsja W. Bachtiar (ed..), Percakapan dengan Sidney Hook tentang 4 Masalah Filsafat: Etika, Ideologi Nasional, Marxisme, dan Eksistensialisme (Jakarta: Penerbit Djambatan, 1986), p. 178.

${ }^{47}$ Nico Syukur Dister OFM, Filsafat Kebebasan, p. 28-9. 
merupakan esensi manusia. Karikatur ini harus ditolak, karena dalam visi antropomorfisme itu, tidak ada tempat untuk kebebasan manusia dan kreatifitasnya. ${ }^{48}$

Apa yang masuk dalam pikiran mereka tentang Tuhan, mereka menyimpulkan itulah Tuhan dalam wujud hakikinya. Ini kesalahan mereka, yang menyamakan pemahaman mengenai Tuhan dengan hakikat Tuhan itu sendiri. Manusia boleh berpikir tentang adanya Tuhan, tetapi adanya Tuhan itu adalah jauh lebih besar daripada apa yang dipikirkan manusia. Pikiran atau konsepsi Tuhan oleh manusia tidaklah sama dengan eksistensi Tuhan itu sendiri.

Memang dalam kehidupan temporal ini, berbicara tentang Tuhan selalu bersifat analogis. Maksudnya bahwa kata-kata yang dipakai itu tidak berlaku bagi Tuhjan dalam arti yang persis sama seperti bagi manusia (ini antropomorfisme), tetapi juga tidak dalam arti yang seluruhnya berlainan (sehingga tidak mengetahui apa-apa tentang Tuhan), melainkan dalam arti yang untuk sebagian sama dan untuk sebagian berlainan. Nico Syukur memberikan contoh untuk hal ini:

Misalkan kita berkata bahwa Allah merupakan "sebab yang transenden". Tetapi kita tidak ada pengalaman tentang sebab-sebab yang transenden. Maka bagaimana kita dapat mendgetahui apakah itu "sebab transenden"? Jalan yang normal untuk mengetahuinya ialah bertolak dari bentuk kausalitas yang tertinggi pada manusia, yakni inisiatif yang bebas, atau pun keputusan yang bebas. Kemudian bukan menerapkan bentuk ini pada Allah (semacam transpalansi atau transposisi) melainkan mengatakan bahwa Allah adalah Dia yang akhirnya memungkinkan keputusanku yang bebas itu sebagai dasarnya yang penghabisan. Tanpa adanya Allah maka keputusanku yang bebas itu pun tidak ada. ${ }^{49}$

"Pada taraf konsep, kita tidak pernah akan dapat memahami bagaimana yang terbatas dapat berkoeksistensi dengan yang tak terbatas." ${ }^{50}$

Eksistensialis ateis menolak eksistensi Tuhan karena menjadikan manusia bergantung sepenuhnya kepada-Nya. Dengan demikian, keaslian eksistensi manusia menjadi hilang. Bagaimanapun, dapat

${ }^{48}$ Louis Lehy, Aliran-aliran Besar Ateisme, p. 68.

${ }^{49}$ Nico Syukur Dister OFM, Filsafat Kebebasan, p. 29.

${ }^{50}$ Louis Leahy, Filsafat Ketuhanan Kontemporer (Yogyakarta: Penerbit Kanisius, 1993), p. 225. 
dimaklumi humanisme mereka, bahwa eksistensi Tuhan tidak dapat tidak memberikan kepada eksistensi manusia suatu corak contingen dan dependen. Dari dirinya sendiri, manusia tidak memiliki apa-apa, sebab Tuhan adalah satu-satunya sumber asali semua hakikat. Tetapi apakah dengan sifat bergantung kepada Tuhan tersebut, kemudian berarti ketiadaan otentisitas eksistensi individu?

Jawaban dari persoalan ini sangat bergantung pada bagaimana Tuhan itu dipahami. Jika Tuhan adalah seperti yang digambarkan Sartre, yaitu disamakan dengan seorang tukang pembuat pisau-pemotongkertas, atau lebih-lebih seperti yang digambarkan dalam karyanya Les Mouches (lalat-lalat), maka bisa dimaklumi bahwa eksistensi Tuhan seperti gambaran itu akan meniadakan otentisitas dan kebebasan manusia. Tetapi, jika Tuhan dipahami seperti digambarkan Iqbal, ${ }^{51}$ yang tidak menghilangkan daya cipta kreatif manusia, maka kesimpulan yang kita ambil akan menjadi lain. Dalam salah satu sajaknya, Iqbal melukiskan penempatan eksistensial antara manusia dan Tuhan sebagai wujud pencipta:

Kau ciptakan malam dan aku buat lampu

Kau ciptakan lempung dan aku menciptakan cawan

Kau ciptakan padang pasir, gunung dan rimba

Aku membuat kebun, taman dan hutan buatan

Akulah yang mengubah racun menjadi obat penawar

Kebesaran manusia terletak dalam daya ciptanya

Bulan bintang Cuma mengulang-ulangi

Kewajiban yang ditetapkan atasnya. ${ }^{52}$

Dari lukisan sajak itu, otentisitas individu manusia diberikan dan diakui oleh Tuhan, seperti sebaliknya manusia dengan aktivitas bebas dan kreatifnya, yang merupakan anugerah Tuhan, bersaksi dan mengakui otentisitas eksistensi-Nya, yang dengan kehendak bebas-Nya menciptakan keaslian eksistensi individu manusia.

Menjawab persoalan di atas, Louis Leahy menegaskan bahwa otentisitas itu tetap dimiliki meskipun itu pemberian Tuhan:

${ }^{51}$ Iqbal sama dengan kaum eksistensialis menekankan dua sifat mendasar manusia yakni kebebasan dan kreativitas. Hal ini dapat disimpulkan dari konsepnya tentang aktivitas ego.

${ }^{52}$ Luce-Claude Maitre, Pengantar ke Pemikiran Iqbal, terj. Djohan Effendi (Bandung: Mizan, 1989), p. 32. 
Tetapi, menerima baik kebenaran itu sama sekali tidak berarti meniadakan otentisitas "ada" saya. Allah yang saya akui justru mempunyai corak mengagumkan berupa mampu untuk memberikan saya kepada saya sendiri. Itulah sesungguhnya perbuatan mencipta, yaitu memberikan sebuah hakikat kepada dirinya sendiri, dan memberinya dengan sungguhsungguh. Kita salam memahami arti penciptaan atau kreasionisme dan kegiatan transenden Allah pada umumnya, jika kita menganggapnya bersaingan dengan kegiatan serta hakikat hal-hal contingen. Adalah kontradiktoris mengemukakan bahwa eksistensi saya, karena telah diberikan kepada saya, maka tidak dapat otentik. Eksistensi itu memang milik saya, karena pemberian itu adalah nyata, asli, dan tidak dapat mempunyai sumber atau alasan lain daripada cinta kasih yang tanpa pamrih sama sekali dari pihak Dia yang merupakan segala-galanya, dan karena kepada sayalah pemberian itu ditujukan. ${ }^{53}$

Penyamarataan arti mencipta Tuhan dengan manusia membuat benda-benda atau hal-hal baru yang diberikan oleh Sartre tersebut mengandung dua kesalahan. Pertama, analogi diputuskan identik dengan kebenaran hakiki, sehingga analogi sebagai fungsi pemahaman - karena manusia tidak dapat memahami secara langsung atau secara konseptual, jadi semacam keterpaksaan penggunaan - dilupakan dan tidak dibedakan dengan apa yang dianalogikan, yang semestinya pengertiannya lebih luas dari sekedar analogi. Kedua, dalam membandingkan Tuhan dengan manusia tersebut, Sartre tidak memunculkan soal ketergantungan manusia kepada Tuhan secara bervariasi. Sartre menganggap bahwa kausalitas Tuhan hanya dapat ada pada semacam sifat yang pengaruh dan akibatnya adalah kebendaan, dan tidak melibatkan kesadaran, sehingga tidak ada persoalan kausalitas yang berkenaan dengan manusia sebagai kebebasan.

Jadi, menurut Leahy, melangkah lewat analogi itu berarti manusia akan bertolak dari pengalamannya dan memperlihatkan bahwa masalah yang dihadapi adalah misterius - misterius ini berarti lebih mengarah ke kesadaran daripada kebendaan - namun bukan karena kealpaan rasio, tetapi rasio diskursif itu harus diatasi. ${ }^{54}$ Pendek kata, "kesukaran konseptual yang dijumpai bukanlah ungkapan dari suatu absurditas

\footnotetext{
${ }^{53}$ Louis Leahy, Aliran-aliran Besar Ateisme, p. 70.

${ }^{54}$ Louis Leahy, Filsafat Ketuhanan Kontemporer, p. 226.
} 
melainkan tanda dari suatu misteri yang terletak dalam tata trans-konseptual (tata yang mengatasi konsep). ${ }^{55}$ Kritik Tuhan dalam visi antropomorfisme ini, sekaligus merupakan tanggapan atas para eksistensialis ateis lainnya, yang pada dasarnya juga berpandangan antropomorfisme terhadap Tuhan. Misalnya, Nietzsche yang menggambarkan Tuhan bermusyawarah dalam sebuah pertemuan yang akhirnya saling tertawa-mengejek satu sama lain. ${ }^{56}$

Karena kaum eksistensialis ateis mengajukan argumentasiargumentasi penolakan Tuhan, maka perlu ditanggapi secara kritis. Alasan mendasar Niezsche menolak Tuhan adalah keyakinannya pada pandangan siklis terhadap kehadiran dunia ini secara abadi, di samping alasan-alasannya yang bersifaat halangan kemajuan pengetahuan dan hambatan kultural karena dominasi gereja. Kritik terhadap alasan Nietzsche ini bisa dilihat dari kritik yang pernah dilakukan oleh Iqbal. Terhadap pandangan siklis atau doktrin Nietzsche tentang Eternal Recurrence, Iqbal menanggapi bahwa dalam doktrin itu, "Tidak ada permulaan atau akhir dari energi yang terus aktif, tidak ada keseimbangan, tidak ada awal dan akhir perubahan." 57 Tanggapannya lebih lanjut, "Tidak ada kejadian baru di alam semesta ini; apa pun yang terjadi sekarang telah terjadi sebelumnya, sejumlah waktu yang tidak terbatas, dan akan terus terjadi pada sejumlah waktu yang tidak terbatas di masa depan." 58

Itu adalah konsekuensi dari Nietzsche's Eternal Recurrence, yang menurut Iqbal tidak lebih hanya merupakan suatu jenis mekanisme yang rapi, yang tidak didasarkan pada suatu fakta yang diketahui, melainkan pada hipotesa ilmu. ${ }^{59}$ Sebagaimana telah disebut di muka bahwa puncak berlangsungnya peristiwa berkesudahan ketika "manusia super" tercapai. Yang berkesudahan itu akan lahir kembali secara abadi atas dasar pandangannya yang siklis. Kelahiran berulang

${ }^{55}$ Ibid.

${ }^{56}$ Will Durant, The Story of Philosophy, p. 416.

${ }^{57}$ Mohammad Iqbal, The Reconstruction of Religious Thought in Islam, reprinted (New Delhi: Nusrat Ali Nasri for Kitab Bhavan 1214, Kalan Mahal, Daryagany, 1981), p. 114 .

\footnotetext{
${ }^{58}$ Ibid., p. 115.

${ }^{59}$ Ibid.
} 
ini bagi Iqbal tidak memberikan aspirasi apa pun.

Kelahirannya tidak dapat dielakkan; bagaimana dapat harapan itu memberikan kepadaku suatu aspirasi (cita-cita)? Kita dapat mencitacitakan hanya terhadap apa yang benar-benar baru, dan yang benarbenar baru ini tidak dapat dipikirkan dalam pandangan Nietzsche yang tidak lebih daripada suatu fatalisme yang terburuk dari sejumlah fatalisme yang ada dalam kata "qiamat". Doktrin seperti itu jauh dari kebenaran diri organisme manusia untuk memperjuangkan kehidupan, cenderung menghancurkan tendensi-tendensi tindakannya dan mengendurkan ketegangan ego. ${ }^{60}$

Dari kritik Iqbal itu menunjukan bahwa Nietzsche yang membunuh Tuhan demi kebebasan itu ternyata, ketika Tuhan sebagai sumber keabadian diganti dengan pandangan siklisnya, kebebasan yang dimaksudkan menjadi semu, bahkan ilusif, karena peristiwa-peristiwa yang terjadi hanyalah perulangan abadi.

Argumentasi kontradiksi internal juga menunjukkan suatu kelemahan, karena realitas ketuhanan hanya disimplifikasi ke dalam dualisme radikal. Seperti diketahui bahwa dasar ontologi Sartre adalah dualisme radikal, being-in-itself dan being-for-itself. Antara keduanya hanya mungkin terdapat ketiadaan, di mana ketiadaan ini merupakan intisari kesadaran. Di sinilah letak keradikalannya, karena jika orang meniadakan jarak antara being-in-itself dan being-for-itself, berarti orang juga meniadakan kesadaran, padahal ia merupakan pusat eksistensi manusia.

Diri sebenarnya manusia adalah being-in-itself, tetapi menuju ke dalamnya tidaklah mungkin, karena kesadaran telah menghalanginya, karena menjadi being-in-itself berarti menjadi benda dan berarti hilangnya kesadaran. Jadi, keinginan manusia adalah sia-sia. Bagi Sartre, menjadi manusia adalah condong untuk menjadi Tuhan. Tetapi, Tuhan pun adalah mustahil, karena jika dikatakan Dia ada, ada-Nya tidak boleh bersifat sadar, dan sekaligus bersifat identik dengan diri-Nya sendiri, dengan meniadakan setiap jarak dari diri-Nya pada diri-Nya, setiap kehampaan. Pada diri Tuhan being-in-itself dan being-for-itself harus tergabung secara mutlak, tetapi bagi Sartre hal ini tidak mungkin, karena bersifat kontradiksi. ${ }^{61}$

\footnotetext{
${ }^{60}$ Ibid., p. 116.

${ }^{61}$ Louis Leahy, Aliran-aliran Besar Ateisme, p. 72.
} 
Pada dasarnya, ontologi Sartre menetapkan keunggulan being-initself, sehingga Tuhan pada akhirnya harus mereduksi diri-Nya sampai pada being-in-itself agar dapat menjadi satu dengan sempurna. Tetapi, lalu Tuhan bukan sadar lagi, ia bukan Tuhan lagi. ${ }^{62} \mathrm{Hal}$ ini adalah benar secara logis, tetapi yang dapat kita bantah adalah ontologinya itu sendiri serta penerapannya yang dilakukannya secara univok pada Tuhan. Louis Leahy menilai bahwa,

Dengan lain perkataan, ia mendefinisikan esensi kesadaran melalui suatu kekurangan kesadaran kita, suatu kekurangan yang disebabkan oleh kenyataan bahwa kesadaran kita terikat pada materi. Kesadaran itu selalu melalui materi, sebab ia tergantung pada pancaindera; itulah sebabnya mengapa persatuan antara yang mengenal dan yang dikenal tidak pernah sempurna; terdapat jarak antara keduanya, karena objektivasi. Namun, mengalihkan bentuk tidak sempurna kesadaran kita kepada Allah merupakan semacam antropomorfisme. Itu berarti tidak melihat bahwa mungkin terdapat suatu roh murni, suatu kehadiran total dari dirinya kepada dirinya tanpa suatu objektivasi apa pun, tanpa suatu jarak apa pun dari dirinya kepada dirinya. ${ }^{63}$

Dengan cara lain, meski pada dasarnya sama, Luijpen mengajukan kritik terhadap ontologi Sartre di atas. Menurutnya, kontradiksi itu berasal dari suatu pengkhianatan yang jelas dari prinsip fundamental pemikiran fenomenologis, yaitu kesatuan implikasi timbal-balik dari subjek dan objek. ${ }^{64}$ Apa artinya "kepenuhan ada" (fullness of being), yang dianggap berasal dari the-in-itself, jika orang menerima bahwa manusia secara berarti hanya bisa berbicara tentang the-in-itself-for-me (berada-dalam-diri-untuk-saya)? The-in-itself-for-me secara pasti tidak tampak sebagai kepenuhan ada. Dapatkah kemudian dibenarkan untuk menarik kembali gerakan intensional dari kesadaran dan mengklaim bahwa the-in-itself meskipun demikian merupakan kepenuhan ada.? ${ }^{25}$ Tuhan yang dipandang sebagai Ada tertinggi, sebagai kepenuhan-ada oleh agama, dibenarkan oleh Luijpen. Tetapi menurutnya, identifikasi kepenuhan tersebut dengan kepenuhan ada dari the-in-itself--nya Sartre adalah tidak benar dan inilah yang membuka sebuah ngarai yang dalam

\footnotetext{
${ }^{62}$ Ibid., p. 73.

${ }^{63}$ Ibid.

${ }^{64}$ William A. Luijpen, Existential Phenomenology, p. 320.

${ }^{65} \mathrm{Ibid}$.
} 
yang tidak dapat dijembatani antara Sartre dan agama. ${ }^{66}$ Penyalahan identifikasi ini, karena Sartre pun sebenarnya juga terjebak pada kontradiksi pemahaman tentang being-in-itself. Letak kontradiksi tersebut adalah ketika ia menyatakan bahwa kesadaran selalu tertambat pada materi (in-itself), selalu bersifat intensional. Adanya materi atau sesuatu ada-lengkap pada dirinya sendiri itu berbeda dengan adanya materi yang dianggap lengkap atau penuh oleh kesadaran. Dengan kata lain, adanya materi tanpa intensionalitas itu berbeda dengan adanya materi yang dilekati intensionalitas. Kontradiksi Sartre terlihat karena ia menyamakan keduanya, sehingga kemudian ia menyamakan Tuhan menurut diri-Nya dengan Tuhan menurut tangkapan kesadarannya.

Dari situ Luijpen menggugurkan anggapan kontradiksi Sartre terhadap Tuhan. "Sartre berpikir bahwa definisi tentang Tuhan adalah suatu kontradiksi tetapi, faktanya, usahanya sendiri untuk berbicara tentang the-in-itself menunjukkan kontradiksi pula." ${ }^{97}$ Hal serupa bisa dibuat berkenaan dengan being-for-itself atau kesadaran:

Berbagai agama menegaskan bahwa Tuhan adalah Ada yang Tertinggi dan bahwa karenanya, Ada-Nya harus terletak pada level kesadaran. Tetapi, ketika Sartre mencabut kesadaran dari semua nilai positif, menolak tingkatan bentuk ada yang tertinggi, dan memahaminya sebagai nihilasi murni, penegasannya bahwa Tuhan dipahami oleh agama sebagai suatu in-itself membuka jurang ngarai yang lain. ${ }^{68}$

\section{E. Kebebasan Koeksistensial antara Manusia dan Tuhan: Kritik-Komparatif Muhammad Iqbal}

Untuk memberi perbandingan konseptual tentang problem koeksistensial antara kebebasan manusia dan Tuhan, dan sekaligus merupakan kritik atas pemikiran eksistensialis ateis di atas, pemikiran seorang filosof muslim besar abad ke-20, yaitu Muhammad Iqbal, perlu dipaparkan di sini. Bagi Iqbal, manusia tidaklah dikutuk atau dihukumi untuk bebas, seperti dengan sangat jelas dan tegas dikatakan Sartre, yang dibahasakan Nietzsche dengan manusia super, melainkan dari kreativitasnya sendiri, manusialah yang memilih kebebasan, karena
${ }^{66}$ Ibid.
${ }^{67}$ Ibid.
${ }^{68}$ Ibid. 
hanya manusia-manusia yang bebaslah yang dapat melampaui batasbatas ruang dan waktu. ${ }^{69}$ Bahkan, pandangan kebebasan Iqbal lebih komprehensif. Baginya, kebebasan bukanlah nilai atau modus eksistensi manusia, melainkan kebebasan adalah kehidupan itu sendiri. ${ }^{70}$

Kebebasan adalah kehidupan itu sendiri, sebab kehidupan merupakan wujud dari kehendak bebas Tuhan. Manusia tidak dihukumi bebas, di mana kebebasan adalah ketiadaan, tetapi manusia menemukan kebebasan dalam kehidupan ini dan kebebasan itu bukan sebagai ketiadaan, melainkan sebagai ke-ada-an, yaitu kehidupan itu sendiri. Bagi Iqbal, menemukan berarti kreasi diri. Dia menerjemahkan kreasi diri mengikuti Ibnu 'Arabi. "Ibnu 'Arabi berpendapat bahwa apa yang diharapkan manusia dari Tuhan, telah diberikan kepadanya. Dengan demikian, manusia sendiri yang memilih individualitas dan kebebasan." 71 Kemauan bebas Tuhan atas kehidupan ini, dengan sendirinya kehidupan ini membawa sifat-sifat dasarnya, yaitu sifat Tuhan sebatas kehidupan yang dikehendaki-Nya. Dengan cara ini manusia "dihadirkan" ke dalam dunia ini bukan dengan sifat-sifat yang sudah jadi, melainkan potensi menuju ke kebebasan, ke kehidupan itu sendiri, bukan menuju ke ketiadaan seperti diyakini Sartre dan Heidegger.

Dengan demikian, Iqbal pun mengutamakan eksistensi daripada esensi. Potensi menuju ke kehidupan, artinya bahwa manusia ada kemudian ia memilih untuk bebas, dan memilih untuk bebas berarti memilih untuk hidup. Jika dicermati, sebenarnya sama dengan Sartre tentang pendapatnya bahwa mula-mula manusia ada, kemudian ia mengisi dirinya. Karena ia berasal dari ketiadaan, maka potensinya condong secara kontinual pada aksi penidakan atau nihilasi terhadap ada. Jadi, perbedaannya, potensi Iqbal menuju ada, sedangkan Sartre menghidari ada.

Pengutamaan Iqbal pada eksistensi manusia ini tercermin dalam pikirannya bahwa manusia mengembangkan dunianya, dan menciptakan nilainya sendiri. Jika dunia sekarang tidak menyumbangkan makna bagi

${ }^{69}$ Wahid Akhtar, "Unsur-unsur Eksistensialis dalam Pemikiran Iqbal," terj. Efendi, Agus dan Abu Bakar, Agus. Al-Hikmah. Maret-Juni, 1990. p. 50 -1.

${ }^{70}$ Ibid., p. 61.

${ }^{71}$ Ibid., p. 51. 
eksistensi manusia, maka dunia itu harus dihancurkan dan dibangun kembali. Dalam sajaknya yang dikutip $\mathrm{Akhtar}^{72}$ dari L. Claude Maitre mengungkapkan hal itu:

Hancurkan dunia sampai berkeping-keping bila tidak sesuai denganmu

Dan ciptakan dunia yang lain dari kedalaman wujudmu

Betapa pedihnya manusia merdeka yang hidup

Di dunia yang diciptakan oleh manusia lain. ${ }^{73}$

Tampak jelas bagaimana prinsip eksistensi manusia mendahului esensi manusia berjalan dalam pemikiran Iqbal. Penghancuran duniaada-sekarang hasil ciptaan manusia bukanlah seperti aksi kontinual penidakan terhadap ada, melainkan suatu penghormatan pada kehidupan yang tidak lain adalah kebebasan itu sendiri. Jadi, bagi Iqbal, ada dunia yang sesuai dengan dirinya, yaitu kehidupan yang di dalamnya manusia menemui kebebasan.

Dalam sikap di atas, Iqbal menegaskan bahwa personalitas nyatanya bukanlah suatu benda, melainkan suatu tindakan. ${ }^{74}$

Pengalamanku hanyalah sederetan dari tindakan-tindakan yang satu sama lain saling berhubungan, dan dipegangi bersama dengan kesatuan tujuan direktif. Seluruh realitas saya terletak dalam sikapku yang direktif. Kamu tidak dapat memahami saya seperti suatu benda dalam ruang, atau sederetan pengalaman dalam aturan temporal; kamu harus menginterpretasikan, memahami, dan mengapresiasikan diriku dalam keputusan-keputusan saya, dalam kehendak sikap-sikap, tujuan-tujuan, dan aspirasi-aspirasi saya. ${ }^{75}$

Ego yang demikian itu bersumber pada sifat hakiki dari ruh atau the soul, yang menurut Iqbal menjadi energi direktif atau petunjuk bagi putusan-putusan tindakan. Sifat dasar ruh atau the soul itu disimpulkan ketika Iqbal menginterpretasikan maknanya dalam al-Qur'an Surah ke17: 85, bahwa ruh itu termasuk amr atau command yang berfungsi sebagai direction (yang mengarahkan, petunjuk). Amr termasuk aktivitas kreatif Tuhan, di samping khalq. Perbedaan keduanya adalah bahwa kalau khalq merupakan creation dan amr merupakan direction. Sebagaimana disebut al-Qur'an sendiri yang artinya "To Him belong creation and

\footnotetext{
${ }_{73}^{72}$ Ibid.

${ }^{73}$ Ibid.

${ }^{74}$ Mohammad Iqbal, The Reconstruction of Religious Thought in Islam, p. 103.

${ }^{75}$ Ibid.
} 
direction." Dari Firman Tuhan itu, Iqbal menyimpulkan "...watak hakiki dari ruh adalah direktif, sebagaimana ia bergerak dari energi direktif Tuhan; walaupun kita tidak mengetahui bagaimana fungsi "direktif" Tuhan sebagai kesatuan-kesatuan ego." "77 Jadi unsur bimbingan dan kontrol direktif dalam aktivitas ego secara jelas menunjukkan bahwa "ego adalah kausalitas personal yang bebas." "78 Kausalitas yang dimaksudkan Iqbal di sini adalah seperti ungkapannya berikut: "Dia (ego) sama-sama mendiami kehidupan dan kebebasan Ego Ultim yang, dengan mengijinkan bangkitnya suatu ego yang terbatas, kemampuan berinisiasi secara pribadi, membatasi kebebasan ini pada kehendak bebas-Nya sendiri."79

Bukankah itu berarti "kontradiksi-diri” dalam al-Qur'an mengenai masalah kehendak bebas dan determinisme. Pernyataan ini pernah dilontarkan oleh R.A. Nicholson, yang kemudian Iqbal menjelaskan maksudnya bahwa apa yang tampak di mata sebagai kontradiktif, pada kenyataannya adalah suatu kebenaran. "Apakah tiap-tiap manusia tidak pernah melewati saat-saat di mana ia merasakan dirinya bebas dan saat-saat di mana ia mengetahui bahwa ia ditentuka oleh Tuhan?" Ditambahkan oleh Iqbal bahwa "kebenaran bukanlah sesuatu yang berwajah tunggal, melainkan suatu kekomplekan berbagai variasi." Bagi Iqbal, meskipun ada determinasi diri tetapi itu tidak berarti meniadakan kebebasan manusia. Sebab determinasi-diri itu tidak lebih dari dan merupakan sifat-sifat kehidupan itu sendiri - sifat-sifat Tuhan yang dilekatkan pada kehidupan yang merupakan realisasi dari Kehendak bebas-Nya sendiri - yang berarti adalah kebebasan itu sendiri. Para eksistensialis ateis telah berusaha mencabut akar determinasidiri ini, tetapi kenyataannya seperti diketahui, Nietzsche terjebak ke dalam determinisme pandangan siklisnya, dan Sartre tidak menyadari

${ }^{76}$ Ibid. Iqbal tidak menyebutkan dalam surah apa dan ayat berapa yang dimaksudkan. Mungkin salah satu ayat yang berisi demikian adalah Q.S. 87: 1 - 3 .

${ }^{77}$ Ibid.

${ }^{78}$ Ibid., p. 108.

${ }^{79}$ Ibid.

${ }^{80}$ Ihsan Ali Fauzi dan Nurul Agustina (ed.), Sisi Manusiawi Iqbal (Bandung: Penerbit Mizan, 1992), p. 69.

${ }^{81}$ Ibid. 
telah masuk ke dalam suatu determinisme dari pandangan ontologi ketiadaan, seperti terlihat dalam aksi nihilasi diri secara terus menerus tanpa kejelasan arah.

Sependapat dengan para eksistensialis, Iqbal mendukung pandangan integritas pemikiran dan tindakan, yang dapat diraih melalui aktivitas ego. Karena kodrat intelek yang membagi dan tidak mempersatukan, maka ia tidak dapat menimbulkan integritas tersebut. Ia memberi pengetahuan tetapi tidak memberi kekuasaan. Ilmu tanpa kekuasaan adalah tidak bermanfaat. Sumber kekuatan dan kekuasaan adalah realisasi diri, yakni realisasi potensi kreativitas dan kebebasan ego. Dengan merealisasikan potensi-potensi ego dan menerjemahkan realisasi tersebut ke dalam perbuatan, individu akan lebih dengan dengan Tuhan. Ia tidak lebur dalam keilahian, tetapi menyerap sifatsifat keilahian ke dalam dirinya. ${ }^{82}$

Pengetahuan merupakan aktivitas kreatif yang tidak pernah gagal, sebab ia merupakan aktivitas kreatif yang berkesinambungan. "Belum"nya manusia adalah pencarian yang tidak pernah berhenti. Ketika pencarian ini berhasil, manusia dapat mengatakan "saya ada." Jelas bahwa Iqbal menisbahkan keilahian kepada ego, dengan penekanan hasrat ingin menyatu dengan sifat-sifat keilahian, bukan hasrat menjadi Tuhan, seperti dipegangi Sartre. Iqbal menyatakan, seperti dikutip Akhtar: "Di dalam sufisme Islam yang lebih tinggi, pengalaman manunggal bukanlah ego terbatas yang menghapuskan identitas dirinya dengan sejenis peleburan ke dalam Ego yang tidak terbatas; tatapi dia hanyalah lintasan yang tidak terbatas dalam pelukan cinta yang terbatas." ${ }^{24}$

Ini berarti pengalaman batin. Pengalaman batin adalah ego yang sedang bekerja, manusia mengepresiasikan ego itu sendiri pada saat ego mempersepsi, menilai, dan berkehendak. Kehidupan ego adalah sejenis tegangan yang disebabkan oleh ego yang menyerbu lingkungan dan lingkungan yang menyerbu ego. Ego tidak berdiri di luar arena saling serbu ini. Ia hadir di dalamnya sebagai energi direktif, dibentuk

\footnotetext{
${ }^{82}$ Wahid Akhtar, Unsur-unsur Eksistentialis dalam Pemikiran Iqbal, p. 56.

${ }^{83}$ Ibid.

${ }^{84}$ Ibid., p. 50.
} 
dan diatur dan sekaligus membentuk dan mengatur pengalamannya sendiri. ${ }^{85}$

Dengan demikian, bisa disimpulkan pendek tentang komparasi Iqbal dan eksistensialis ateis ketika bicara problem koeksistensial antara kebebasan manusia dan Tuhan. Kalau eksistensialis ateis melihat adanya pengungkungan kebebasan manusia dalam Tuhan, Iqbal menyelamatkan kebebasan manusia justru karena hidup dalam dunia dengan Tuhan.

\section{F. Kesimpulan}

Setelah menyelami argumentasi penolakan Tuhan oleh eksistensialis ateis, ternyata muncul kontradiksi-kontradiksi pula. Sebagai contoh, ketika menghindari esensi atau hakikat manusia, eksistensialis ateis mengusulkan kebebasan harus absolut yang mekanismenya adalah nihilasi terus menerus, tetapi kebebasan absolut ini kemudian justru menjadi karakter hakiki dari manusia, atau suatu esensi tentang manusia juga. Bahkan, kebebasan absolut itu justru tidak menumbuhkan suatu kebebasan sama sekali, karena setidaknya menerima pandangan orang lain meski hanya sebagian dilarang. Pelarangan adalah salah satu bentuk ketidakbebasan. Logika determinisme pun telah membawa mereka kepada suatu determinisme baru. Penolakan Tuhan terpaksa membawa mereka untuk berpikir keras mengenai bagaimana menjelaskan awal dan akhir keberadaan manusia, dan jawabannya justru jauh lebih tidak bermakna, misalnya doktrin eternal recurrence Nietzsche yang justru menyemukan perbuatan manusia dan kebebasan yang mirip seperti kerja mekanik robot.

Penting, akhirnya, bagi mereka yang beragama untuk banyak menyelami pemikiran-pemikiran para ateis untuk mengetahui argumentasi-argumentasi mereka dan kemudian menjawabnya dengan argumentasi-argumentasi pula, untuk mematahkan mereka. Karena, kalau ingin mengetahui kritik yang berani terhadap agama, justru harus mendengar dan membaca dari mereka yang tidak suka kepada agama atau para ateis. Kalau mendengar dari para agamawan atau teis, sudah barang tentu tidak akan ada kritik yang mendasar. Kemampuan menjawab kritik para ateis akan semakin mendewasakan keberagamaan para teis.

${ }^{85}$ Ibid., p. 54. 


\section{BIBLIOGRAFI}

Akhtar, Wahid. "Unsur-unsur Eksistensialis dalam Pemikiran Iqbal".'Terj. Efendi, Agus dan Abu Bakar, Agus. Al-Hikmah. MaretJuni, 1990.

Altizer, Thomas J.J.and Hamilton, William. Radical Theology and the Death of God. New York: The Bobb Merrill Company, Inc., 1966.

Arifin, Choirul. Kehendak untuk Berkuasa Friedrich Nietasche. Jakarta: Penerbit Airlangga, 1987.

Bachtiar, Harsja W. (penyt.). Percakapan dengan Sidney Hook tentang 4 Masalah Filsafat: Etika, Ideologi Nasional, Marxisme, dan Eksistensialisme. Jakarta: Penerbit Djambatan, 1986.

Bixler, Julius Seelye. "Nietzsche.” Vergilius Ferm (ed.). An Encyclopedia of Religion. New York: Philosophical Library, 1976.

Blackham, H.J. Six Existentialist Thinkers. London: Routledge \& Kegan Paul, 1952.

Durant, Will. The Story of Philosophy. New York: Pocket Books, Inc. 1954.

Fakry, Madjid. Ethical Theories in Islam. Leiden: E. J. Brill, the Nederlands, 1991.

Goldman, Alvin I. "Actions, Predictions, and Books of Life." Joel Feinberg (ed.). Reason and Responsibility, Readings in Some Basic Problems of Philosophy. California: Wadsworth Publishing Company Belmont, 1985.

Gould, James A. (ed.). Classic Philosophical Questions. Columbus: Charles E. Merrill Publishing Company a Bell \& Howell Company, 1971.

Hadiwijono, Harun. Sari Sejarah Filsafat Barat 2. Yogyakarta: Penerbit Kanisius, 1993.

Hammersma, Harry. Tokoh-tokoh Filsafat Barat Modern. Jakarta: PT. Gramedia, 1983.

Husayni Bahesty, Muhammad dan Bahonar, Javad. Dasar Pemikiran Filsafat Islam dalam Al-Qur'an. Terj. Sofyan Abubakar. Jakarta: Risalah Masa, 1991. 
Iqbal, Mohammad The Reconstruction of Religious Thought in Islam. Reprinted. New Delhi: Nusrat Ali Nasri for Kitab Bhavan 1214, Kalan Mahal, Daryagany, 1981.

Leahy, Louis. Aliran-aliran Besar Ateisme Tinjanan Kritis. Yogyakarta: Penerbit Kanisius, 1992.

Leahy, Louis. Filsafat Ketuhanan Kontemporer. Yogyakarta: Penerbit Kanisius, 1993.

Luijpen, William A. Existential Phenomenology. New York: Duquesne University Press, Pittsburgh, Pa., 1960.

Maitre, Luce-Claude. Pengantar ke Pemikiran Iqbal. Terj. Djohan Effendi. Bandung: Mizan, 1989), p. 32.

Moltmann, Juergen. "The Risks of Freedom." Werner Becher, Alastair V. Campbell, and G. Keith Parker (eds.). The Risks of Freedom. Manila: the Pastoral Care Foundation, Inc., 1993.

Nauman, Jr., St. Elmo. The New Dictionary of Existentialism. New York: Philosophical Library, 1971.

Nietzsche, Friedrich. The Joyful Wisdom. Trans. By Thomas Common. London: NTN Voulis, (t.t).

Nietzsche, Friedrich. Thus Spake Zarathustra. Trans. By Thomas Common. London: George Allen \& Unwin Ltd., 1967.

Peursen, C.A. van. Orientasi di Alam Filsafat. Terj. Dick Hartoko (Jakarta: PT. Gramedia, 1980.

Pojman, Louis. Philosophy the Pursuit of Wisdom. Belmont: Wadsworth Publishing Company, 1998.

Sartre, Jean-Paul. Being and Nothingness, an Essay on Phenomenological Ontology. Trans. by H. Barnes. New York: Philosophical Library, 1956.

Sartre, Jean-Paul. Existentialism and Human Emotions. Trans. by Bernard Frechtman. New York: Philosophical Library, 1948.

Sudiardja, A.. "Pergulatan Manusia dengan Allah dalam Antropologi Nietzsche." M. Sastrapratedja (ed.). Manusia Multi Dimensional Sebuah Renungan Filsafat. Jakarta: PT. Gramedia, 1983. 
Eksistensialisme Ateistik tentang Eksistensi Tuhan

Syukur Dister OFM, Nico. Filsafat Kebebasan. Yogyakarta: Penerbit Kanisius, 1993.

Wahl, Jean. A Short History of Existentialism. Trans. by Forrest Williams and Stanley Maron. New York: Philosophical Library, 1949. 